\title{
STUDI PEMANFAATAN SUMBER DAYA ALAM KABUPATEN INHIL DALAM PEMBUATAN MIE SAGU FORTIFIKASI IKAN GABUS DAN TELUR
}

\author{
Rifni Novitasari \\ Program Studi Teknologi Pangan, Fakultas Pertanian, Universitas Islam Indragiri \\ Email: rifnivita@gmail.com
}

\begin{abstract}
Research on the Utilization of Natural Resources in INHIL Regency in Making Sago Noodles Fortified for Cork Fish and Eggs has been conducted on September 28 to October 2 2020. The research was conducted with 3 treatments, namely $A$ = Sago flour: Cork Fish meat porridge $=300 \mathrm{gr}: 200 \mathrm{gr}, \mathrm{B}=$ sago flour: snakehead fish meat porridge $=325 \mathrm{gr}: 175 \mathrm{gr}$, and $\mathrm{C}=$ sago flour: cork fish meat porridge $=350 \mathrm{gr}: 150 \mathrm{~g}$ then from each treatment analysis was carried out using the test method Hedonic involving 20 trained panelists. From the analysis, it is known that the best treatment is treatment $A$ based on the initial appearance with a score of 7.85 for color, a score for texture 8.05, a score for taste 6.50 and a score for aroma 7.
\end{abstract}

Keywords: Sago noodles, snakehead fish, fortification

\begin{abstract}
Abstrak
Telah dilakukan penelitian tentang "Studi Pemanfaatan Sumber Daya Alam Kabupaten INHIL dalam Pembuatan Mie Sagu Fortifikasi Ikan Gabus dan Telur pada tanggal dari tanggal 28 September sampai dengan 2 Oktober 2020. Adapun penelitian dilakukan dengan 3 Perlakuan yakni $A=$ Tepung sagu : Bubur daging Ikan Gabus $=300 \mathrm{gr}: 200 \mathrm{gr}, \mathrm{B}=$ Tepung sagu : Bubur daging Ikan Gabus = $325 \mathrm{gr}: 175 \mathrm{gr}$, dan C = Tepung sagu : Bubur daging Ikan Gabus = $350 \mathrm{gr}: 150 \mathrm{gr}$ kemudian dari masing - masing perlakuan dilakukan analisa dengan menggunakan metode Uji Hedonik dengan melibatkan 20 orang panelis terlatih. Dari hasil analisa diketahui bahwa perlakuan terbaik adalah perlakuan $A$ berdasarkan penampilan awal dengan skor terhadap warna 7,85, skor terhadap tekstur 8,05, skor terhadap rasa 6,50 dan skor aroma 7.
\end{abstract}

Kata kunci: Mie sagu, ikan gabus, fortifikasi

\section{PENDAHULUAN}

\subsection{Latar Beakang}

Sagu (Metroxylon sagu Rottb) adalah salah satu sumber karbohidrat andalan Indonesia yang luas lahannya tersebar di beberapa wilayah, yakni : di Papua, Sulawesi, Maluku, Riau dan Kalimantan. Dikutib dari data Kementrian Koordinator Perekonomian yang dilansir Darmawan, D dan Zuraya, N. (2020) cit Novitasari, R (2020), luas sagu di dunia mencapai 6,5 juta hectare (ha). Dari luasan itu, sebanyak 5,43 juta ha atau $83,4 \%$ terdapat di Indonesia.

Anonim, (2018) cit Novitasari, R (2020) menguraikan bahwa di Provinsi Riau adalah salah satu pusat potensi sagu dihasilkan di 2 Kabupaten yakni Kabupaten Indragiri Hilir dan Kabupaten Kepulauan Meranti. Potensi produksi sagu di Inhil dengan hamparan sagu alam yang termasuk budidaya semi sekitar 10 ton / Ha / tahun. Potensi tersebut lebih tinggi dibandingkan potensi sagu di Papua yang mencapai sekitar 5 ton/ Ha. Karena itu jika dilakukan budidaya secara intensif diperkirakan potensi hasil pati sagu dapat meningkat menjadi 15 ton /ha.

Tepung sagu memiliki beberapa kelebihan dibandingkan tepung terigu, tepung sagu mengandung pati yang tidak tercerna yang yang penting bagi kesehatan pencernaan, yaitu "resistant starch" (RS) yang memiliki efek seperti serat makanan (Lisan, H., Deswita dan Syahrul, 2014).

Badan Penelitian dan Pengembangan Pertanian (2019) menguraikan bahwa Resistant starch" (RS) berfunsi menjaga kesehatan usus, sebagai prebiotik, dan mampu menurunkan indeks glikemik. Kadar RS mie sagu sekitar 3-4 kali dari RS dalam mie instan dari terigu. Lebih lanjut dijabarkan bahwa mengkonsumsi mie sagu 
tidak akan menimbulkan lonjakan kadar glukosa dalam darah sehingga aman bagi penerita diabetes mellitus.

Persentase karbohidrat yang terdapat pada mie sagu ini sangat tinggi yaitu $80 \%$, namun dari kandungan protein sangat rendah. Berdasarkan Direktoral Gizi, Depkes RI (1990) cit Lisani, H et all (2014), kandungan protein yang terdapat pada mie sagu yaitu $<0,7 \%$. Hal ini merupakan salah satu factor pembatas untuk mengembangkan produk-produk makanan berbasis sagu sebagai produk pangan yang bernilai gizi tinggi. Melalui fortifikasi sumber pangan protein tinggilah yang dapat mengatasi kekurangan kandungan protein pada produk pangan berbasis sagu.

Disamping kaya akan hasil pertanian dan perkebunan, Kabupaten Indragiri Hilir kaya akan hasil perikanannya, khusunya ikan air tawar yakni ikan gabus (Channa striata) mengandung protein jenis albumin yang berfungsi untuk mengatur tekanan dalam pembuluh darah tidak bocor ke jaringan tubuh sekitarnya.

Kondisi dimasa pandemi Covid-19 yang merata diseluruh dunia bahkan diseluruh Indonesia, mengharuskan masyarakat untuk memenuhi kebutuhan gizi dan pangan berbasis pangan lokal, dan mengharuskan mereka bisa mendiversifikasi produk olahan pangannya agar dalam pemenuhan nutrisi yang komplit agar imun tubuh meningkat tidak bosan, terutama untuk konsumsi anak. Salah satu bentuk olahan pangan yang berbasis sumber daya lokal di Kabupaten Indragiri Hilir adalah mie sagu yang telah difortifikasi dengan protein dari telur dan ikan gabus.

\subsection{Perumusan Masalah}

Ikan gabus memiliki bentuk yang tidak menarik seperti ular dengan moncong seperti lele, membuat sumber protein hewani ini kurang diminati, terlebih -lebih oleh anakanak, khususnya balita. Padahal menurut Novitasari, R (2020), peran utama albumin di dalam tubuh sangat penting, yaitu membantu pembentukan jaringan sel baru serta mempercepat penyembuhan pascaoperasi dan melahirkan.

Sagu yang selama ini dibuat menjadi mie sagu yang khas bagi Provinsi Riau, khususnya Kabupaten Kepulauan Meranti, warnanya masih gelap, proses pengerjaannya secara umum membutuhkan waktu yang lama, karena proses perendaman, pemotongan manual dengan menggunakan pisau dan penyisihan mie yang dihasilkan untuk mengurangi kadar air untuk mie sagu basah, dan hanya kaya akan sumber Karbohidrat saja.

Untuk itu dilakukan penelitian terhadap formulasi dan proses produksi mie sagu yang di fortifikasi dengan sumber protein hewani yang diperoleh dari telur dan ikan gabus sehingga dihasilkan mie sagu yang kaya akan sumber karbohidrat dan protein yang dibutuhkan untuk meningkatkan imun tubuh, khususnya pada orang tua usia lanjut dan anak-anak, dan dapat diproduksi secara cepat untuk skala rumah tangga.

\subsection{Tujuan Penelitian}

Penelitian ini bertujuan menentukan formulasi dan prosedur yang tepat dalam membuat mie sagu yang telah difortifikasi dengan protein hewani dari telur dan ikan gabus.

\section{METODA PENELITIAN}

\subsection{Tempat dan Waktu Penelitian}

Penelitian ini dilakukan di rumah Jalan Kesadaran Blok C No.1 Pekanbaru, yang analisa organoleptiknya dengan menggunakan uji hedonic skala 9 dilakukan dengan melibatkan 20 orang tetangga disekitar rumah. Penelitian dilakukan pada tanggal 28 September sampai dengan 2 Oktober 2020.

\subsection{Peralatan dan Bahan}

Adapun peralatan dan bahan yang digunakan dalam proses pembuatan mie fortifikasi adalah sebagai berikut :

Peralatan : Baskom ukuran sedang, kompor gas, wajan anti lengket, gelas ukur, timbangan, dandang untuk merebus, pengaduk / spatula, ampia listrik, chopper, kuali ukuran sedang.

Bahan : tepung sagu sesuai perlakuan, bubur ikan gabus sesuai dengan perlakuan, 1 sendok teh soda kue, garam halus $1 \mathrm{sdm}, 200 \mathrm{ml}$ air minum, baking powder $1 / 2 \mathrm{sdt}$, dan telur ayam ras, tepung terigu secukupnya untuk membaluri adonan mie sagu.

\section{RANCANGAN PENELITIAN}

Penelitian ini dilakukan dengan beberapa perlakuan terhadap formula terhadap mie sagu fortifikasi dengan bahan utama tepung sagu dan ikan gabus.

Adapun perlakuan percobaan yang dilakukan pada penelitian ini adalah perlakuan kombinasi antara tepung sagu dan 
bubur daging ikan gabus seperti yang diuraikan berikut ini :

$A=$ Kombinasi 300 gr tepung sagu +200 gr bubur daging ikan gabus

$B=$ Kombinasi 325 gr tepung sagu +175 gr bubur daging ikan gabus

$\mathrm{C}=$ Kombinasi 350 gr tepung sagu +150 gr bubur daging ikan gabus

Mie yang dihasilkan dalam penelitian ini adalah mie basah, yang kemudian dilakukan uji organoleptic dengan menggunakan metoda uji hedonik skala 9 terhadap : warna, rasa, aroma dan tekstur. Sampel uji organoleptik nantinya berupa mie sagu yang telah diolah menjadi mie sagu goreng.

Analisa dilakukan terhadap tingkat kesukaan panelis terlatih dengan menggunakan uji hedonik skala 9.

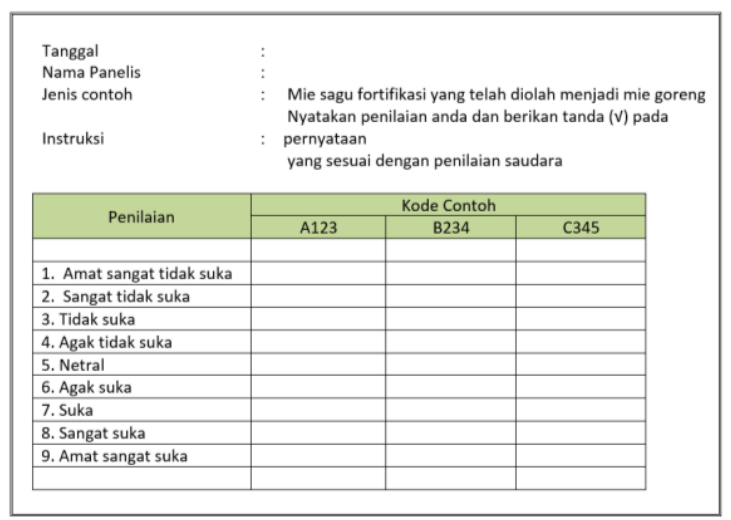

Berikut ini akan ditampilkan diagram pembuatan mie sagu fortifikasi dengan protein hewani dari telur dan ikan gabus:

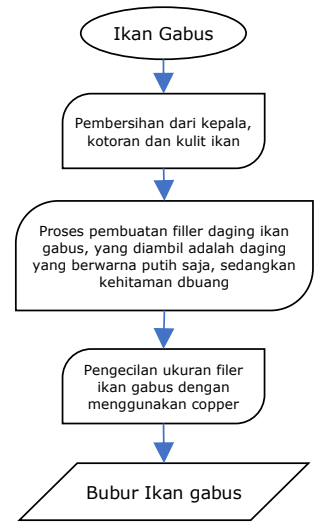

Gambar 1. Proses Pembuatan Bubur Ikan

Setelah bubur ikan gabus dibuat, berikutnya kita masuk ke langkah pembuatan mie sagu fortifikasi seperti yang digambarkan oleh diagram alir berkut ini:

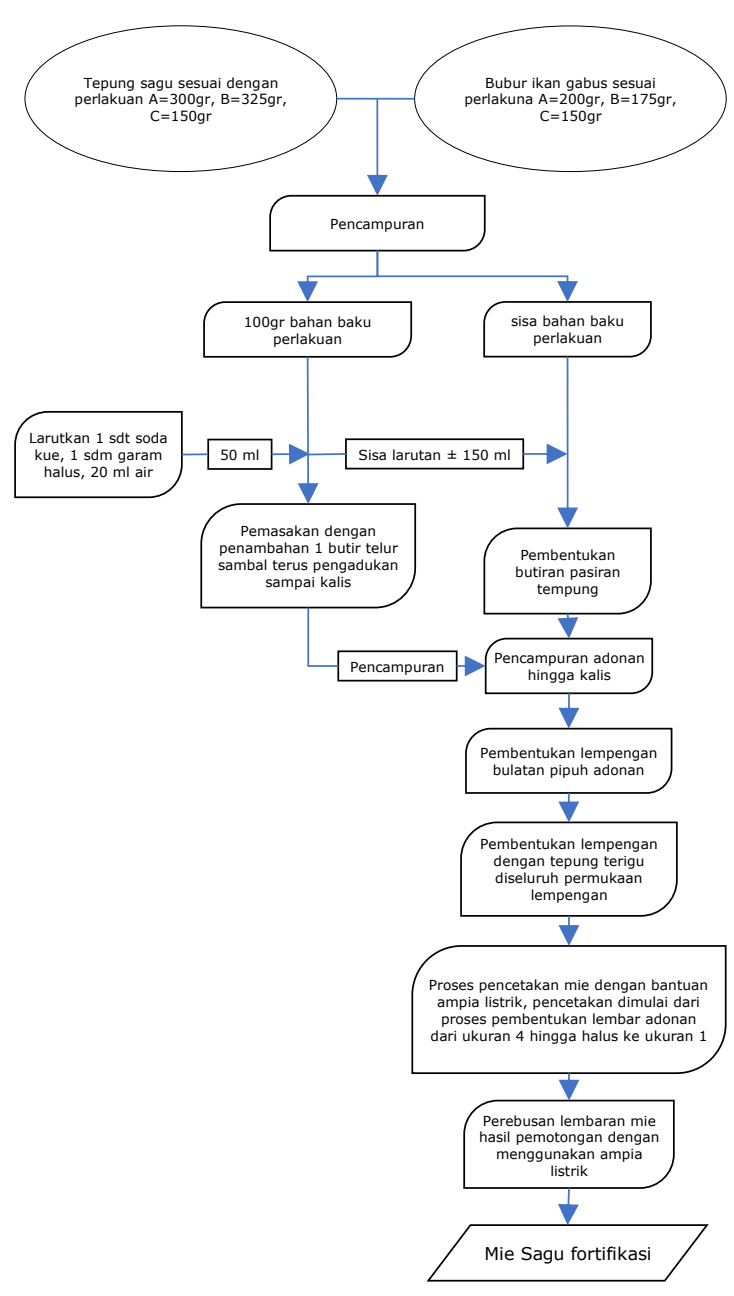

Gambar 2. Proses Pembuatan Mie Sagu

Berikut ini adalah gambar mie sagu fortifikasi dan gambar mie sagu fortifikasi yang telah diolah menjadi mie goreng spesial yang akan dijadikan objek pada uji organoleptic dengan menggunakan metode uji hedonic.

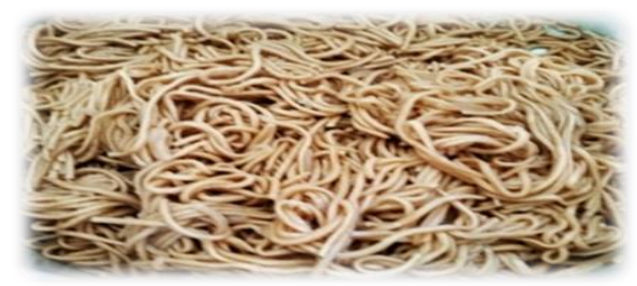

Gambar 3. Mie sagu Fortifikasi 


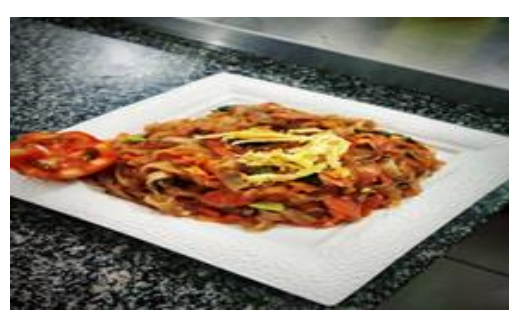

Gambar 4. Mie sagu fortifikasi goreng spesial

\section{HASIL DAN PEMBAHASAN}

Uji hedonik atau kesukaan lazim digunakan untuk memilih produk yang lebih diminati/ disukai apabila dibandingkan dengan produk lain. Menurut Setyaningsih, D., dkk Uji hedonik ini juga dapat diaplikasikan pada saat pengembangan produk atau perbandingan produk dengan produk pesaing. Berikut hasil uji hedonik dari studi pembuatan mie sagu yang difortifikasi dengan ikan gabus dan telur yang diolah menjadi mie sagu fortifikasi goreng yang dihasilkan.

\subsection{WARNA}

Dari hasil analisa dengan menggunakan ANOVA dan uji lanjut dengan menggunakan metode DNMRT diperoleh hasil sebagai berikut :

Tabel 1. Hasil uji hedonik terhadap warna mie sagu fortifikasi dari ikan gabus dan telur

\begin{tabular}{|l|c|}
\hline \multicolumn{1}{|c|}{ Perlakuan } & $\begin{array}{c}\text { Rerata } \\
\text { Perlakuan }\end{array}$ \\
\hline $\begin{array}{l}\text { A : T.sagu : Bubur daging Ikan Gabus }=300 \\
\text { gr: } 200 \mathrm{gr}\end{array}$ & $7,85 \mathrm{a}$ \\
B : T.sagu : Bubur daging Ikan Gabus $=325$ & $7,45 \mathrm{~b}$ \\
gr: $175 \mathrm{gr}$ & $6.55 \mathrm{c}$ \\
$\begin{array}{l}\text { C }: \text { T.sagu : Bubur daging Ikan Gabus }=350 \\
\text { gr: } 150 \mathrm{gr}\end{array}$ & \\
\hline
\end{tabular}

Angka-angka yang terletak pada lajur yang sama yang diikuti oleh huruf kecil yang sama berbeda tidak nyata pada taraf $5 \%$ menurut DNMRT

Dari Tabel 1. Diketahui bahwa perlakuan A lebih disukai dibandingkan perlakuan B dan C. Semakin banyak tepung sagu yang digunakan, dan semakin sedikit pemanfaatan ikan gabus sebagai protein fortifikasi pada mie yang dibuat, maka nilai penerimaan terhadap warna mie sagu olahan semakin kecil dalam arti kurang disukai.

Tepung sagu sebagai pengganti pemakaian tepung terigu pada produk olahan, menyebabkan produk olahan memiliki warna agak keruh bila dibandingkan apabila dalam pengolahan yang sama menggunakan tepung terigu. Semakin banyak tepung sagu yang digunakan maka semakin pekat warna keabu-abuan dari produk olahan yang dihasilkan. Hal ini diperkuat dari hasil penelitian Rumapar, $M$ (2015) yang mengatakan penurunan nilai kenampakan mie basah sangat berkaitan erat dengan warna dari sagu yang mengalami proses pencoklatan enzymatis. Dengan bertambahnya penggunaan sagu maka semakin berkurang kesukaan panelis.

\subsection{RASA}

Dari hasil analisa dengan menggunakan ANOVA dan uji lanjut dengan menggunakan metode DNMRT diperoleh hasil sebagai berikut :

Tabel 2. Hasil uji hedonik terhadap rasa mie sagu fortifikasi dari ikan gabus dan telur

\begin{tabular}{|l|c|}
\hline \multicolumn{1}{|c|}{ Perlakuan } & $\begin{array}{c}\text { Rerata } \\
\text { Perlakuan }\end{array}$ \\
\hline C : T.sagu : Bubur daging Ikan Gabus $=$ & $7.80 \mathrm{ab}$ \\
$350 \mathrm{gr}: 150 \mathrm{gr}$ & $7.45 \mathrm{~b}$ \\
B : T.sagu : Bubur daging Ikan Gabus $=$ & \\
$325 \mathrm{gr}: 175 \mathrm{gr}$ \\
$\begin{array}{l}\text { A : T.sagu : Bubur daging Ikan Gabus }= \\
300 \mathrm{gr}: 200 \mathrm{gr}\end{array}$ \\
\hline
\end{tabular}

Angka-angka yang terletak pada lajur yang sama yang diikuti oleh huruf kecil yang sama berbeda tidak nyata pada taraf $5 \%$ menurut DNMRT

Berdasarkan Tabel 2., diketahui bahwa rasa mie sagu fortifikasi dengan ikan gabus dan telur perlakuan $\mathrm{C}$ lebih disukai dengan skor 7,80 dibandingkan rasa olahan mie fortifikasi B $(7,45)$ dan A $(6,50)$. Semakin banyak bubur ikan gabus yang ditambahkan ke dalam bahan mie sagu fortifikasi, semakin pekat rasa ikannya, semakin kurang diminati oleh panelis. Hal ini juga didukung oleh hasil penelitian Rumapar, M (2015) yang menyatakan bahwa terjadinya penurunan nilai rasa mie basah masing- masing perlakuan sejalan dengan pertambahan tingkat fortifikasi tepung ikan.

\subsection{AROMA}

Dari hasil analisa dengan menggunakan ANOVA dan uji lanjut dengan menggunakan metode DNMRT diperoleh hasil sebagai berikut :

Tabel 3. Hasil uji hedonik terhadap aroma mie sagu fortifikasi dari ikan gabus dan telur

\begin{tabular}{|l|c|}
\hline \multicolumn{1}{|c|}{ Perlakuan } & $\begin{array}{c}\text { Rerata } \\
\text { Perlakuan }\end{array}$ \\
\hline $\begin{array}{l}\text { C : T.sagu : Bubur daging Ikan Gabus }= \\
350 \mathrm{gr}: 150 \mathrm{gr}\end{array}$ & $8,5 \mathrm{a}$ \\
$\mathrm{B}:$ T.sagu : Bubur daging Ikan Gabus $=$ & $7,6 \mathrm{~b}$ \\
$325 \mathrm{gr}: 175 \mathrm{gr}$ & \\
$\begin{array}{l}\text { A : T.sagu : Bubur daging Ikan Gabus }= \\
300 \mathrm{gr}: 200 \mathrm{gr}\end{array}$ & $7,0 \mathrm{c}$ \\
\hline
\end{tabular}

Angka-angka yang terletak pada lajur yang sama yang diikuti oleh huruf kecil yang sama berbeda tidak nyata pada taraf 5\% menurut DNMRT 
Dari hasil uji lanjut diketahui bahwa mie sagu fortifikasi dari perlakuan C (T.sagu : Bubur daging Ikan Gabus = $350 \mathrm{gr}: 150 \mathrm{gr}$ ) lebih disukai aromanya dengan skor 8,5 dibandingkan perlakuan B T.sagu : Bubur daging Ikan Gabus = 325 gr : 175 gr) dengan skor 7,6 dan perlakuan A (T.sagu : Bubur daging Ikan Gabus = 300 gr : 200 gr) dengan skor 7,0. Bila dikaitkan dengan hasil uji organoleptic untuk rasa, maka diketahui bahwa tingkat kesukaan terhadap aroma mie sagu yang di fortifikasi, berbanding lurus dengan tingkat kesukaan terhadap rasa mie sagu fortifikasi tsb. Semakin banyak bubur ikan yang digunakan pada mie fortifikasi, maka tingkat kesukaan terhadap aroma dan rasa semakin menurun, $\mathrm{Hal}$ ini tidak terlepas dari aroma dan rasa dari bubur ikan gabus yang digunakan. Hal ini didukung oleh pernyataan Rumapar, M (2015) yang menyatakan bahwa penurunan nilai aroma mie basah dikarenakan bau amis yang ditimbulkan oleh aroma tepung ikan, dan adanya reaksi browning non enzimatik (pencoklatan) mempengaruhi aroma dari mie basah yang dihasilkan sehingga mengurangi nilai kesukaan panelis. Umumnya panelis akan menyukai bahan pangan jika mempunyai aroma khas yang tidak menyimpang dari aroma normal. Jadi semakin banyak ikan yang ditambahkan, aroma yang ditimbulkan akan semakin keras.

\subsection{TEKSTUR}

Dari hasil analisa dengan menggunakan ANOVA dan uji lanjut dengan menggunakan metode DNMRT diperoleh hasil sebagai berikut :

Tabel 4. Hasil uji hedonik terhadap tekstur mie sagu fortifikasi dari ikan gabus dan telur

\begin{tabular}{|l|c|}
\hline \multicolumn{1}{|c|}{ Perlakuan } & Rerata Perlakuan \\
\hline A : T.sagu : Bubur daging Ikan Gabus & \\
300 gr: 200 gr & $8,05 \mathrm{a}$ \\
B : T.sagu : Bubur daging Ikan Gabus $=$ & \\
325 gr: 175 gr & $7,25 \mathrm{~b}$ \\
C $:$ T.sagu : Bubur daging Ikan Gabus $=$ & \\
350 gr: 150 gr & $6.75 \mathrm{c}$ \\
\hline
\end{tabular}

Angka-angka yang terletak pada lajur yang sama yang diikuti oleh huruf kecil yang sama berbeda tidak nyata pada taraf 5\% menurut DNMRT

Berdasarkan hasil uji lanjut terhadap tekstur mie sagu fortifikasi dari ikan gabus dan telur pada Tabel 4, diketahui bahwa perlakuan $\mathrm{A}$ ( T.sagu : Bubur daging Ikan Gabus $=300 \mathrm{gr}$ : 200 gr) lebih disukai dengan skor 8,05 dibandingkan mie sagu fortifikasi B (T.sagu : Bubur daging Ikan Gabus = $325 \mathrm{gr}: 175 \mathrm{gr}$ ) dengan skor 7,25 dan C (T.sagu : Bubur daging Ikan Gabus = $350 \mathrm{gr}: 150 \mathrm{gr}$ ) dengan skor 6,75. Hal ini disebabkan semakin banyak tepung sagu yang dijadikan bahan baku olahan, maka produk yang dihasilkan akan memiliki tekstur terlalu lembek dan terlalu lembut sehingga butuh bahan yang bisa memperkuat teksturnya (Wijaya, YG, 2020)

\section{KESIMPULAN}

Dari hasil penelitian diketahui bahwa perlakuan A (T.sagu : Bubur daging Ikan Gabus = $300 \mathrm{gr}: 200 \mathrm{gr}$ ) adalah perlakuan terbaik dalam pembuatan mie sagu yang di fortifikasi dengan protein dari ikan gabus dan telur analisa uji hedonik baik itu dari segi warna, rasa ,aroma dan teksrur yang melibatkan 20 orang panelis terlatih.

\section{DAFTAR PUSTAKA}

[1] Balai Besar Litbang Pascapanen , 2019. Tahukan Anda >> Mie Sagu Baik Untuk Kesehatan. Artikel. Kementrian Pertanian Badan LITBANG Pertanian. Bogor. Libang pertanian.go.id . diakses tanggal 3 November 2020.

[2] Darmawan, D dan Zuraya, N., 2020. Potensi Besar, 83 Persen Lahan Sagu Dunia Ada di Indonesia, Artikel Republika, Republika co.id , Tanggal 16 Juni 2020, 16.32 WIB diakses 28 Oktober 2020.

[3] Lisan, H., Deswita dan Syahrul, 2014. Kajian Pengolahan Mie Sagu Konsentrat Protein Ikan Patin (Pangasius hypophthalmus) Instan yang Difortifikasi Tepung Bayam (Amaranthus sp). Ejournal. Fakultas Perikanan dan Ilmu Kelautan, Universitas Riau. Pekanbaru.

[4] Novitasari, R. 2020. Pembuatan Bakso Ikan Gabus Dengan Pemanfaatan Tepung Sagu yang Merupakan Potensi Lokal Sumber Daya Alam Kabupaten Indragiri Hilir. E-Journal Teknologi Pangan. Vol.p, No. 2 (2020), terbit tanggal $03-11-2020$

[5] Rumapar, M (2015). Fortifikasi Tepung Ikan (Decapterus sp) pada Mie Basah yang Menggunakan Tepung Sagu sebagai Suvsitusi Tepung Terigu, Majalah BIAM Vol.11 NO.1, Juki 2015, Hal. 26 - 36, diakses tanggal 3 November 2020.

[6] Wijaya, YG., 2020. Bedanya Tepung Sagu dan Tepung Tapioka, Kenali 
Sebelum Bikin Kue . Artikel. Kompas.com Tanggal 30 Juni 2020.

Diakses tanggal 29 Oktober 2020. 